\title{
Impact of Smoking and Alcohol Consumption on Oxidative Status in Male Infertility and Sperm Quality
}

\author{
SHALAKA S. RAMGIR AND V. G. ABILASH* \\ Department of Biomedical Sciences, School of Biosciences and Technology, VIT, Vellore- 632 014, India
}

Ramgir and Abilash: Smoking and Alcohol in Male Infertility

\begin{abstract}
The most common unhealthy lifestyle factors like cigarette smoking and drinking alcohol have controversial reports on how these impact male fertility. The present study assessed the potential effects of these habits on sperm quality, male reproductive hormones, and blood plasma oxidative profile in 133 infertile men with 124 fertile, healthy controls. Among the participants, 28 (10.8 \%), 29 (11.2 \%), 33 (12.8\%), 34 (13.2\%) fertile men were non-alcoholics and non-smokers (total abstainers), smokers, alcohol drinkers, and smokers plus alcohol drinkers, respectively. On the other hand, 32 (12.4 \%), 30 (11.6\%), 34 (13.2 \%), 37 (14.3\%) infertile men were total abstainers, smokers, alcohol drinkers, and smokers plus alcohol drinkers, respectively. The conventional sperm parameters and reproductive hormone levels were found to be significantly different in the subsets of infertile men than those of fertile men $(\mathbf{p}<\mathbf{0 . 0 0 1})$. In these subsets of infertile men, blood plasma malondialdehyde, nitric oxide concentrations were significantly higher and superoxide dismutase, reduced glutathione activities were significantly lower when compared to fertile men and infertile men total abstainers group ( $<\mathbf{0 . 0 0 1}$ ). In infertile subjects, particularly smoking-alcohol drinking group was more affected than only smoking or alcohol drinking groups. Furthermore, these oxidative markers were correlated with sperm concentration, motility, and morphology, except nitric oxide concentration, which was only associated with sperm motility. These findings highlighted that blood plasma antioxidants are as efficient as seminal plasma antioxidants in male fertility evaluation.
\end{abstract}

Key words: Smoking, alcohol, oxidative stress, semen quality, male infertility

Male infertility is a multifactorial syndrome with an extensive range of causative conditions ${ }^{[1]}$ from anatomical problems ${ }^{[2]}$ to undesirable lifestyle and environmental factors ${ }^{[3-7]}$. Age, diet, workout, stress, usage of recreational and prescription drugs, alcohol drinking, cigarette smoking, regular consumption of caffeine, preventive care and environmental and occupational exposures may have a positive or negative impact on fertility ${ }^{[5]}$. Environmental or lifestyle factors cause oxidative stress in germ lines of men, which increases the risk of getting childhood cancer and other congenital diseases in their progenies ${ }^{[8]}$. However, until now, studies reported controversial results about the effects of toxic substances among these lifestyle and environmental factors on spermatozoa ${ }^{[5,9,10]}$. Such conflicting data could be because of the studies were conducted either in general (healthy) men or infertile men $^{[11]}$. When it comes to unhealthy lifestyle factors, smoking and alcohol consumption usually comes on top of the list. Many earlier studies reported the harmful effect of cigarette smoking on sperm quality, hormonal

*Address for correspondence E-mail: abilash.vg@vit.ac.in

September-October 2019 imbalance, higher seminal leukocyte concentrations ${ }^{[11]}$ and its correlation with increased reactive oxygen species (ROS) leve ${ }^{[12,13]}$. However, the negative effect of cigarette smoking on male reproductive health is refuted by other studies that included fertile smoking men with children ${ }^{[14]}$. Mostafa explained that smoking might not affect fertility potential in some smokers, but it would be advantageous for smokers with low semen quality to quit smoking ${ }^{[13]}$. Furthermore, tobacco smoke included several mutagens, which can affect the future generations. Genotoxic substances in cigarette smoke can affect DNA integrity and viability of spermatozoa ${ }^{[15]}$.

Heavy alcohol drinking ( $\geq 5$ episodes of binge drinking in the past month) ${ }^{[9]}$ has been reported to

This is an open access article distributed under the terms of the Creative Commons Attribution-NonCommercial-ShareAlike 3.0 License, which allows others to remix, tweak, and build upon the work non-commercially, as long as the author is credited and the new creations are licensed under the identical terms

Accepted 20 August 2019

Revised 27 May 2019

Received 21 Janaury 2019

Indian J Pharm Sci 2019;81(5):933-945 
be associated with increased ROS generation ${ }^{[16]}$. Ethanol when metabolized in the body, one of the metabolites, acetaldehyde interacts with proteins and lipids to produce protein adducts and peroxidation of lipids, respectively ${ }^{[17]}$. Maneesh et al. concluded that oxidative stress in the testes of alcoholics significantly lowers testosterone and antioxidant activities along with increased lipid peroxidation (LPO) levels ${ }^{[18]}$. Moreover, Varshini et al. concluded that a negative effect of alcohol consumption is associated with the damage of sperm $\mathrm{DNA}^{[19]}$. According literature, very little evidence is found regarding the mechanisms of alcohol-induced oxidative damage to the male reproductive system. Till now, numerous studies reported a negative impact of imbalanced seminal plasma antioxidant or oxidative stress markers on semen parameters in infertile men ${ }^{[20-23]}$. Most of these studies compared the correlation between antioxidant activities of blood and seminal plasma on sperm profile in infertile men and confirmed their close relationship with each other ${ }^{[24,25]}$. Researchers observed that similar to seminal plasma antioxidants, blood antioxidants also associated with semen quality in infertile men as compared with fertile (healthy) controls ${ }^{[24]}$. These findings suggest that blood antioxidants could be a valuable diagnostic tool for evaluating sperm quality potential ${ }^{[26]}$. Therefore, this study mainly focused on blood antioxidants since their correlation with sperm quality has been less emphasized. In this study, an attempt was made to assess the effects of smoking and alcohol drinking on sperm quality, male reproductive hormone levels, oxidative stress, malondialdehyde (MDA), nitric oxide (NO) and antioxidant profiles that included superoxide dismutase (SOD), reduced glutathione (GSHr) to find a correlation between sperm quality and oxidative damage level of smoking plus alcohol-exposed infertile men.

\section{MATERIALS AND METHODS}

Thiobarbituric acid (TBA), butylated hydroxytoluene (BHT), n-butanol solution, ethylenediaminetetraacetic acid (EDTA), nitro blue tetrazolium (NBT), reduced nicotinamide adenine dinucleotide (NADH) and phenazine methosulfate (PMS) were obtained from HiMedia Pvt. Ltd, Mumbai. All other supplementary reagents used were of analytical grade.

\section{Study design and participants:}

In this retrospective observational study, the sample size was calculated by using a two-sided test. Hence, 489 men were recruited from the outpatient department of Sandhya Fertility Clinic, Vellore, India, who visited for the treatment of primary couple's infertility. Out of 489 recruited men, 354 men were approved to participate in this research. Institutional Ethical Committee of VIT approved this study with human subjects (reference no. VIT/IECH/004b/April 16, 2016). Demographic information, semen, and blood samples were collected from all of the volunteers after obtaining written informed consent. From those 354 volunteers, 97 men were excluded from this study who fulfilled the following exclusion criteria, participants who described with secondary couple infertility (due to presence of other co-factors that might interfere with interpretations of this study), subjects with history of $\mathrm{Y}$ chromosome microdeletion, chromosomal abnormalities, abnormal liver function, cryptorchidism, vasectomy, the use of recreational drug (e.g. marijuana or any narcotic agents), antioxidant or medicinal therapy in the past 3 months before enrolment or exposure to gonadotoxins such as radiotherapy, chemotherapy and/or pesticides.

Finally 257 men were included in this study who fulfilled the following inclusion criteria, men of 18 to $45 \mathrm{y}$ of age with a report of primary couple infertility and had smoking and/or drinking habits. Patients only with male factor infertility were included, which is confirmed after a complete gynecological evaluation of the female partners. Healthy Men with normal semen parameters and proven paternity without assisted reproductive technologies (ART) were selected as the controls. All patients were subjected to a routine follow up as complete genital and physical examination, hormonal and semen assessment before starting any treatment. Among 257 participants, 124 fertile men were considered as controls and 133 were primary infertile men. Total participants were divided into different groups according to their smoking and/or drinking habits such as, fertile control subjectssmokers (29), alcohol drinkers (33), smokers+alcohol drinkers (34) and total abstainers (who never smoked or drank alcohol before 28), Infertile subjects- smokers (30), alcohol drinkers (34), smokers+alcohol drinkers (37) and total abstainers (32; fig. 1). Among included participants, smokers have smoked at least 20 cigarettes/ day or more for at least one year, plus alcohol drinkers were drinking at least $40 \mathrm{~g}$ of alcohol daily for at least one year. 


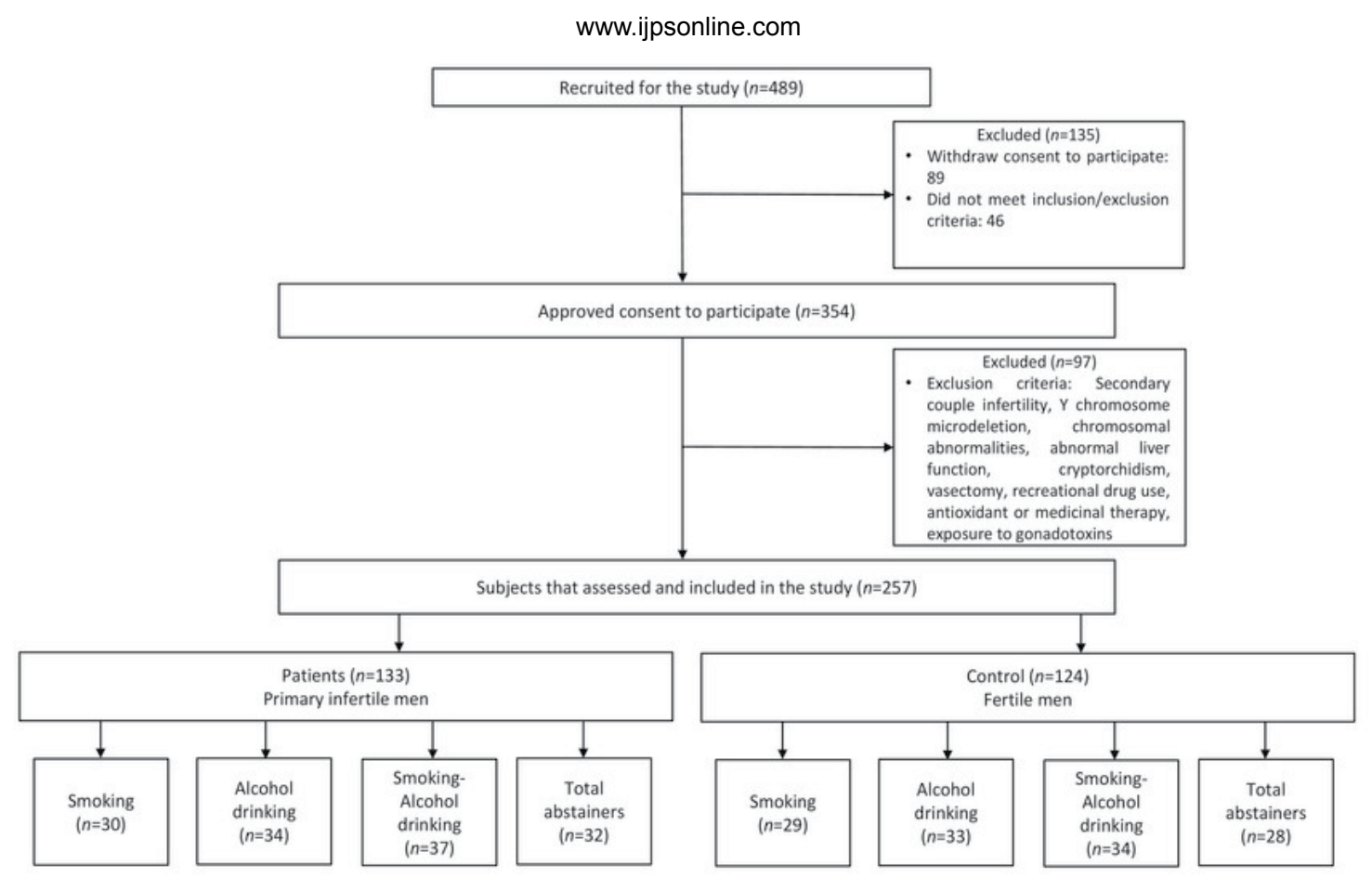

Fig. 1: Flow diagram of study subjects

\section{Questionnaire and physical examination:}

A questionnaire containing demographic information, medical history, smoking and/or alcohol consumption habits, use of any other drugs was noted from all volunteers with the help of a trained clinician before the physical investigation. Overall physical, as well as genital analysis, was done by a certified clinician. Furthermore, semen and blood samples were collected from volunteers. Only one sample per participant was involved in this study.

\section{Semen analysis, blood collection, serum separation and hormone assay:}

All men gave a semen sample by masturbation in a semen collection room. The time of sexual abstinence was for 4-6 d. The ejaculate sample was collected in a sterile, dry, leak-proof wide-mouth container. The collected semen samples were allowed to liquefy in an incubator at $37^{\circ}$ and the macroscopic and microscopic examination was performed according to the World Health Organization, 2010 guidelines ${ }^{[27]}$. The variables taken in consideration were semen volume $(\mathrm{ml})$, sperm concentration $\left(\mathrm{n} \times 10^{6} / \mathrm{ml}\right)$, total sperm motility (progressive+non-progressive \%), morphologically normal sperms (\%) and seminal leukocyte concentration $\left(\mathrm{n} \times 10^{6} / \mathrm{ml}\right)$.

From all the subjects fasting blood samples were collected by venepuncture and were transferred to sterile plain vacutainers safely. Serum samples were collected after centrifugation (1000 g 15 min after blood coagulation) within $1 \mathrm{~h}$ of sample collection. The serum was stored at $-20^{\circ}$ for future examinations like either hormone or oxidative damage parameters ${ }^{[28]}$.

The male reproductive hormones in serum samples were measured using Cobas e411 analyser with platform electrochemiluminescence immunoassay technique (Roche Diagnostics, Mannheim, Germany) and the normal range for $\mathrm{LH}, \mathrm{FSH}$, testosterone, and prolactin hormones were $4-11 \mathrm{mIU} / \mathrm{ml}, 2-10 \mathrm{mIU} / \mathrm{ml}$, $2-12 \mathrm{ng} / \mathrm{ml}$ and $2-18 \mathrm{ng} / \mathrm{ml}$, respectively ${ }^{[29]}$.

\section{Examination of oxidative stress and antioxidant measurement:}

$\mathrm{LPO}^{[30]}$ levels in serum were measured by a modified TBA assay method. Thirty microliters serum, $150 \mu \mathrm{l}$ of homogenization buffer and $150 \mu 1$ TBA reagent were mixed. Additionally, $2 \mu \mathrm{l}$ of BHT was added to hinder LPO artificially in the experiment. This mixture was incubated at $100^{\circ}$ for $15 \mathrm{~min}$. Then, the solution was thawed at room temperature. n-Butanol solution $(0.3 \mathrm{ml})$ was added to the above mixture and centrifuged at $15000 \mathrm{rpm}$ for $3 \mathrm{~min}$. The fluorescence was read at $530 \mathrm{~nm}$ by an ELISA plate reader (ELx800 from BioTEK). The final concentration was calculated according to the MDA standard curve. MDA levels are denoted as $\mu \mathrm{M}$. $\mathrm{NO}^{[31]}$ was evaluated in serum using Griess reagent. The absorbance was calculated at $540 \mathrm{~nm}$ that describes exact nitrite concentrations $\left(\mathrm{NO}_{2}-\right)$. The concentration was calculated according 
to the sodium nitrite standard curve. $\mathrm{NO}_{2}-$ levels were expressed as $\mu \mathrm{M} / \mathrm{ml}$.

SOD was determined via the microplate method, and it was denoted by the previously reported method in blood serum ${ }^{[32]}$. In detail, $25 \mu \mathrm{l}$ of serum was added to $200 \mu \mathrm{l}$ of freshly prepared mixture consist of EDTA $(0.1 \mathrm{mM}), \mathrm{NBT}(62 \mu \mathrm{M}), \mathrm{NADH}(98 \mu \mathrm{M})$ in phosphate buffer at $\mathrm{pH} 7.4(50 \mathrm{mM})$. Then, $25 \mu \mathrm{l}$ of PMS $(33 \mu \mathrm{M}$ in $50 \mathrm{mM}$ of phosphate buffer at $\mathrm{pH} 7.4$ that contains $0.1 \mathrm{mM}$ EDTA) was added into the mixture. The final mixture was incubated for $5 \mathrm{~min}$ at room temperature and measured at $560 \mathrm{~nm}$ using an ELISA plate reader. The SOD activity was expressed as U/g protein.

GSHr levels of the serum were determined using the human reduced glutathione ELISA kit (K125407, Kinesis Dx, USA). GSHr concentrations were expressed as $\mu \mathrm{mol} / 1$. The data calculations, calibration, and standard curve fitting were completed according to the manufacturer's protocol. The protein amount in serum was assessed by Bradford's method using bovine serum albumin as the standard ${ }^{[33]}$.

\section{Statistical analysis:}

Statistical analysis was done using the GraphPad version 5.0 (GraphPad Software, San Diego, CA). Results were expressed as mean \pm standard deviation (SD). To determine significant differences in MDA, NO, SOD, GSHr, semen, and reproductive hormones levels between fertile and infertile men with respect to their smoking and/or alcohol habits, pair-wise comparisons between the study groups were made using one-way analysis of variance (ANOVA) followed by the posthoc Tukey's multiple comparison test. Pearson's correlation analysis was performed to determine the coefficients of correlations.

\section{RESULTS AND DISCUSSION}

General and clinical features of the fertile and infertile participants according to their smoking and/or alcohol use are described in Table 1. Age in years and bodymass index (BMI) in $\mathrm{kg} / \mathrm{m}^{2}$ of fertile $(36.72 \pm 4.06$ and $20.99 \pm 1.3)$ and infertile men $(36.69 \pm 4.5$ and $21.24 \pm 1.25)$ did not differ significantly with respect to their smoking and/or alcohol use. Among the volunteers participated, most of the cases studied up to high school and were residing in urban areas.

Semen parameters, along with male reproductive hormone levels, were described in Table 2. Semen volume, sperm concentration, total sperm motility and normal forms of sperm were normal in smokers and/ or alcohol drinker and total abstainer groups of fertile donors whereas, these parameters were significantly lower in smokers, alcohol drinkers, smokers+alcohol drinkers and total abstainers among infertile subjects $(p<0.001)$. Furthermore, these parameters were significantly lower, especially in smokers+alcohol drinkers group than other subgroups of infertile men. Seminal leukocyte concentrations in smokers and/ or alcohol drinkers groups of infertile men were significantly higher specifically in smokers+alcohol

TABLE 1: GENERAL AND CLINICAL CHARACTERISTICS OF STUDY PARTICIPANTS IN TERMS OF SMOKING AND/OR ALCOHOL USE STATUS

\begin{tabular}{|c|c|c|c|c|c|c|c|}
\hline \multirow[b]{2}{*}{ Covariates } & \multirow[b]{2}{*}{ Age $(y)$} & \multicolumn{3}{|c|}{ Education } & \multicolumn{2}{|c|}{ Area } & \multirow[b]{2}{*}{$\mathrm{BMI}\left(\mathrm{kg} / \mathrm{m}^{2}\right)$} \\
\hline & & Illiterate (\%) & $\begin{array}{l}\text { High school } \\
\text { (12th) (\%) }\end{array}$ & $\begin{array}{l}\text { Graduate or } \\
\text { higher (\%) }\end{array}$ & Rural (\%) & Urban (\%) & \\
\hline \multicolumn{8}{|l|}{ Fertile subjects } \\
\hline Total (124) & $36.72 \pm 4.06$ & 16.1 & 62 & 21.7 & 27.4 & 72.5 & $20.99 \pm 1.3$ \\
\hline Smokers (29) & $37.2 \pm 2.19$ & 13.7 & 62 & 24.1 & 27.5 & 72.4 & $20.96 \pm 1.05$ \\
\hline Alcohol drinkers (33) & $37.69 \pm 3.81$ & 18.1 & 60 & 21.2 & 24.2 & 75.7 & $21.12 \pm 1.26$ \\
\hline Smoker+alcohol drinkers (34) & $36.61 \pm 5.07$ & 17.6 & 61.1 & 20.5 & 29.4 & 70.5 & $21.14 \pm 1.1$ \\
\hline Total abstainers (28) & $35.21 \pm 4.21$ & 14.2 & 64.2 & 21.4 & 28.5 & 71.4 & $20.67 \pm 1.76$ \\
\hline \multicolumn{8}{|l|}{ Infertile subjects } \\
\hline Total (133) & $36.69 \pm 4.5$ & 15.7 & 63.1 & 21 & 27 & 72.9 & $21.24 \pm 1.25$ \\
\hline Smokers (30) & $35.33 \pm 5.7$ & 16.6 & 63.3 & 20 & 26.6 & 73.3 & $20.8 \pm 1.64$ \\
\hline Alcohol drinkers (34) & $37.94 \pm 3.5$ & 11.7 & 61.7 & 26.4 & 26.4 & 73.5 & $21.44 \pm 1.15$ \\
\hline Smoker+alcohol drinkers (37) & $37.05 \pm 4.34$ & 16.21 & 64.8 & 18.9 & 27 & 72.9 & $21.24 \pm 1.23$ \\
\hline Total abstainers $(n=32)$ & $36.21 \pm 4.12$ & 18.25 & 62.5 & 18.75 & 28.1 & 71.8 & $21.46 \pm 0.8$ \\
\hline
\end{tabular}

Data are expressed as the mean \pm standard deviation when appropriate or as percent (\%) when categorical. (One-way ANOVA followed by Tukey's multiple comparison test) 
TABLE 2: SEMEN PARAMETERS IN FERTILE AND INFERTILE SUBJECTS IN TERMS OF SMOKING AND/ OR ALCOHOL USE STATUS

\begin{tabular}{|c|c|c|c|c|c|c|c|c|c|}
\hline Covariates & $\begin{array}{l}\text { Semen } \\
\text { volume } \\
(\mathrm{ml})\end{array}$ & $\begin{array}{c}\text { Sperm } \\
\text { concentration } \\
\left(\times 10^{6} / \mathrm{ml}\right)\end{array}$ & $\begin{array}{c}\text { Sperm } \\
\text { total } \\
\text { motility } \\
(\%) \\
\end{array}$ & $\begin{array}{c}\text { Sperm } \\
\text { morphology } \\
\text { (\% normal } \\
\text { forms) }\end{array}$ & $\begin{array}{c}\text { Seminal } \\
\text { leukocytes } \\
\left(\times 10^{6} / \mathrm{ml}\right)\end{array}$ & $\underset{(\mathrm{mlU} / \mathrm{ml})}{\mathrm{FSH}}$ & $\begin{array}{c}\text { LH } \\
(\mathrm{mlU} / \mathrm{ml})\end{array}$ & $\begin{array}{c}\text { Testosterone } \\
(\mathrm{ng} / \mathrm{ml})\end{array}$ & $\begin{array}{c}\text { Prolactin } \\
(\mathrm{ng} / \mathrm{ml})\end{array}$ \\
\hline \multicolumn{10}{|l|}{ Fertile subjects } \\
\hline Total (124) & $\begin{array}{c}3.23 \\
\pm 0.58^{*}\end{array}$ & $\begin{array}{l}85.12 \\
\pm 23.38^{*}\end{array}$ & $\begin{array}{l}56.33 \\
\pm 7.16^{*}\end{array}$ & $56.33 \pm 7.16^{*}$ & $0.08 \pm 0.18^{*}$ & $\begin{array}{c}4.81 \\
\pm 2.13^{*}\end{array}$ & $\begin{array}{c}6.67 \\
\pm 1.40^{*}\end{array}$ & $7.3 \pm 2.06^{*}$ & $8.69 \pm 3.16$ \\
\hline Smokers (29) & $\begin{array}{c}3.22 \\
\pm 0.65\end{array}$ & $\begin{array}{c}81.34 \\
\pm 23\end{array}$ & $\begin{array}{l}54.65 \\
\pm 5.77\end{array}$ & $22.37 \pm 4.66$ & $0.1 \pm 0.2$ & $\begin{array}{c}4.91 \\
\pm 2.38\end{array}$ & $\begin{array}{r}7.05 \\
\pm 1.35\end{array}$ & $7.97 \pm 1.54$ & $9.31 \pm 3.55$ \\
\hline $\begin{array}{l}\text { Alcohol drinkers } \\
\text { (33) }\end{array}$ & $\begin{array}{l}3.32 \\
\pm 0.6\end{array}$ & $\begin{array}{l}88.27 \\
\pm 19.94\end{array}$ & $\begin{array}{l}57.24 \\
\pm 7.54\end{array}$ & $24.81 \pm 5.3$ & $0 \pm 0$ & $\begin{array}{l}5.48 \\
\pm 2.18\end{array}$ & $\begin{array}{c}6.68 \\
\pm 1.48\end{array}$ & $7.17 \pm 1.66$ & $9.2 \pm 3.15$ \\
\hline $\begin{array}{l}\text { Smoker+alcohol } \\
\text { drinkers (34) }\end{array}$ & $\begin{array}{l}2.92 \\
\pm 0.46\end{array}$ & $\begin{array}{c}80.79 \\
\pm 23.93\end{array}$ & $\begin{array}{l}53.7 \\
\pm 7.2\end{array}$ & $22.47 \pm 3.79$ & $0.2 \pm 0.2$ & $\begin{array}{r}4.84 \\
\pm 1.92\end{array}$ & $\begin{array}{r}6.35 \\
\pm 1.39\end{array}$ & $6.59 \pm 2.08$ & $7.64 \pm 3.2$ \\
\hline $\begin{array}{l}\text { Total abstainers } \\
\text { (28) }\end{array}$ & $\begin{array}{c}3.52 \\
\pm 0.43^{\#}\end{array}$ & $\begin{array}{c}90.57 \\
\pm 26.23^{\#}\end{array}$ & $\begin{array}{c}60.17 \\
\pm 6.37^{\#}\end{array}$ & $26.21 \pm 4.55^{\#}$ & $0 \pm 0$ & $\begin{array}{c}3.86 \\
\pm 1.77^{\#}\end{array}$ & $\begin{array}{c}6.67 \\
\pm 1.33^{\#}\end{array}$ & $7.63 \pm 2.65^{\#}$ & $8.75 \pm 2.45$ \\
\hline \multicolumn{10}{|c|}{ Infertile subjects } \\
\hline Total (133) & $\begin{array}{c}1.47 \\
\pm 0.68^{*}\end{array}$ & $\begin{array}{c}36.95 \\
\pm 24.08^{*}\end{array}$ & $\begin{array}{l}47.45 \\
\pm 9.18^{*}\end{array}$ & $47.45 \pm 9.18^{*}$ & $1.28 \pm 0.75^{*}$ & $\begin{array}{l}10.03 \\
\pm 3.3^{*}\end{array}$ & $\begin{array}{c}9.91 \\
\pm 2.21^{*}\end{array}$ & $2.58 \pm 1.88^{*}$ & $8.57 \pm 3.62$ \\
\hline Smokers (30) & $\begin{array}{c}1.29 \\
\pm 0.28^{n}\end{array}$ & $\begin{array}{l}25.53 \\
\pm 4.65\end{array}$ & $\begin{array}{l}41.33 \\
\pm 4.05^{\wedge \Uparrow}\end{array}$ & $4.4 \pm 3.69^{\wedge} \pi$ & $1.6 \pm 0.4$ & $\begin{array}{c}10.8 \\
\pm 1.33^{n}\end{array}$ & $\begin{array}{c}11.13 \\
\pm 0.67^{\wedge \Uparrow}\end{array}$ & $1.71 \pm 1.75^{ף}$ & $8.94 \pm 3.57$ \\
\hline $\begin{array}{l}\text { Alcohol drinkers } \\
\text { (34) }\end{array}$ & $\begin{array}{c}1.67 \\
\pm 0.71^{\neq}\end{array}$ & $\begin{array}{c}41.23 \\
\pm 6.31^{\neq \downarrow}\end{array}$ & $\begin{array}{c}53.41 \\
\pm 6.92^{\wedge \neq}\end{array}$ & $19.44 \pm 4.87^{\wedge \neq}$ & $1.5 \pm 0.4$ & $\begin{array}{c}10.2 \\
6 \pm 2.58\end{array}$ & $\begin{array}{c}7.2 \\
\pm 1.93^{\wedge \neq \downarrow}\end{array}$ & $3.25 \pm 1.5^{\ddagger}$ & $7.87 \pm 3.59$ \\
\hline $\begin{array}{l}\text { Smoker+alcohol } \\
\text { drinkers (37) }\end{array}$ & $\begin{array}{c}1.12 \\
\pm 0.67^{\neq \$}\end{array}$ & $\begin{array}{c}14.24 \\
\pm 4.51^{\ddagger \$}\end{array}$ & $\begin{array}{l}40.05 \\
\pm 2.68^{\neq \$}\end{array}$ & $3.48 \pm 3.84 \neq \$$ & $1.8 \pm 0.2$ & $\begin{array}{l}11.05 \\
\pm 4.67^{\lessgtr}\end{array}$ & $\begin{array}{c}11.3 \\
\pm 0.92^{\neq \$}\end{array}$ & $1.64 \pm 1.67 \$$ & $9.06 \pm 3.92$ \\
\hline $\begin{array}{l}\text { Total abstainers } \\
(\mathrm{n}=32)\end{array}$ & $\begin{aligned} & 1.85 \\
& \pm 0.69^{\# 115}\end{aligned}$ & $\begin{array}{c}69.37 \\
\pm 23.16^{\# \mid I_{1} S}\end{array}$ & $\begin{array}{l}55.43 \\
\pm 8.83^{\# \# \mid S}\end{array}$ & $18.31 \pm 5.44^{\# \Uparrow \$ s}$ & $0.1 \pm 0.2^{1 / 3 \$}$ & $\begin{array}{c}7.9 \\
\pm 2.39^{\# n_{1}, 5}\end{array}$ & $\begin{aligned} & 9.12 \\
\pm & 2.79^{\# 11 ! S}\end{aligned}$ & $3.78 \pm 1.67^{\# 1 \neq 5}$ & $8.41 \pm 3.39$ \\
\hline
\end{tabular}

Data are expressed as the mean \pm standard deviation. ${ }^{*} p$ values indicate significant difference by control group, ${ }^{\#} p$ values indicate significant difference by control group (among total abstainers), "p; 'p; \$ $p$; ${ }^{\wedge}$; ${ }^{\ddagger} p$ values indicate significant difference by smokers versus total abstainers; alcohol drinkers versus total abstainers; smokers+alcohol drinkers versus total abstainers; smokers versus alcohol drinkers; alcohol drinkers versus smokers+alcohol drinkers respectively except smokers versus smokers+alcohol drinkers (for direct comparison of smokers+alcohol drinkers with total abstainers among infertile men)

drinkers group when compared to total abstainers group in infertile men along with fertile men subgroups $(p<0.001)$. In fertile participants, seminal leukocyte concentrations in smokers and/or alcohol drinkers groups were higher than the total abstainers group but were not significantly different. Amongst 133 infertile men, 101 men were smokers and/or alcohol drinkers who showed significantly higher FSH, LH and lower testosterone levels than those of 124 fertile men $(p<0.001)$. However, infertile men did not demonstrate any significant difference in prolactin hormone level when compared to the control of fertile subgroups. Among infertile men subgroups, smokers+alcohol drinkers group was more affected than other smokers and/or alcohol drinkers subgroups.

LPO concentrations were expressed as serum MDA content in the smokers $(57.34 \pm 2.55)$, and alcohol drinkers (51.96 \pm 4.82$)$, smokers+alcohol drinkers $(60.43 \pm 6.59)$ and total abstainers $(45.53 \pm 3.34)$ of infertile patients was found to be significantly higher than that of same smokers and/or alcohol drinkers groups in fertile men $(\mathrm{p}<0.001)$. Also, the mean NO levels in the serum of smokers and/or alcohol drinkers groups of infertile men were significantly higher when compared to the corresponding fertile men subgroups $(p<0.001)$. Both MDA and NO concentrations among the smokers and/or alcohol drinkers subgroups of fertile men showed higher levels than those of total abstainers, while their mean levels were not significantly different; whereas in infertile men it was significantly different. Moreover, these levels were significantly elevated in smokers+alcohol drinkers group, particularly when compared to only smokers or alcohol drinkers subgroups in infertile men (Table 3 ).

Table 3 demonstrates SOD and GSHr levels in serum of fertile and infertile subjects. The SOD activity and GSHr levels were significantly lower in infertile men than those of fertile men $(p<0.001)$. In statistical comparisons of SOD and GSHr status, it was noted that smokers and/or alcohol drinker's subgroups of fertile men showed lower mean values than those of total abstainers in fertile men, but these values were 
TABLE 3: IMPACT OF SMOKING AND ALCOHOL DRINKING ON BLOOD MDA, NO, SOD AND GSHr LEVELS

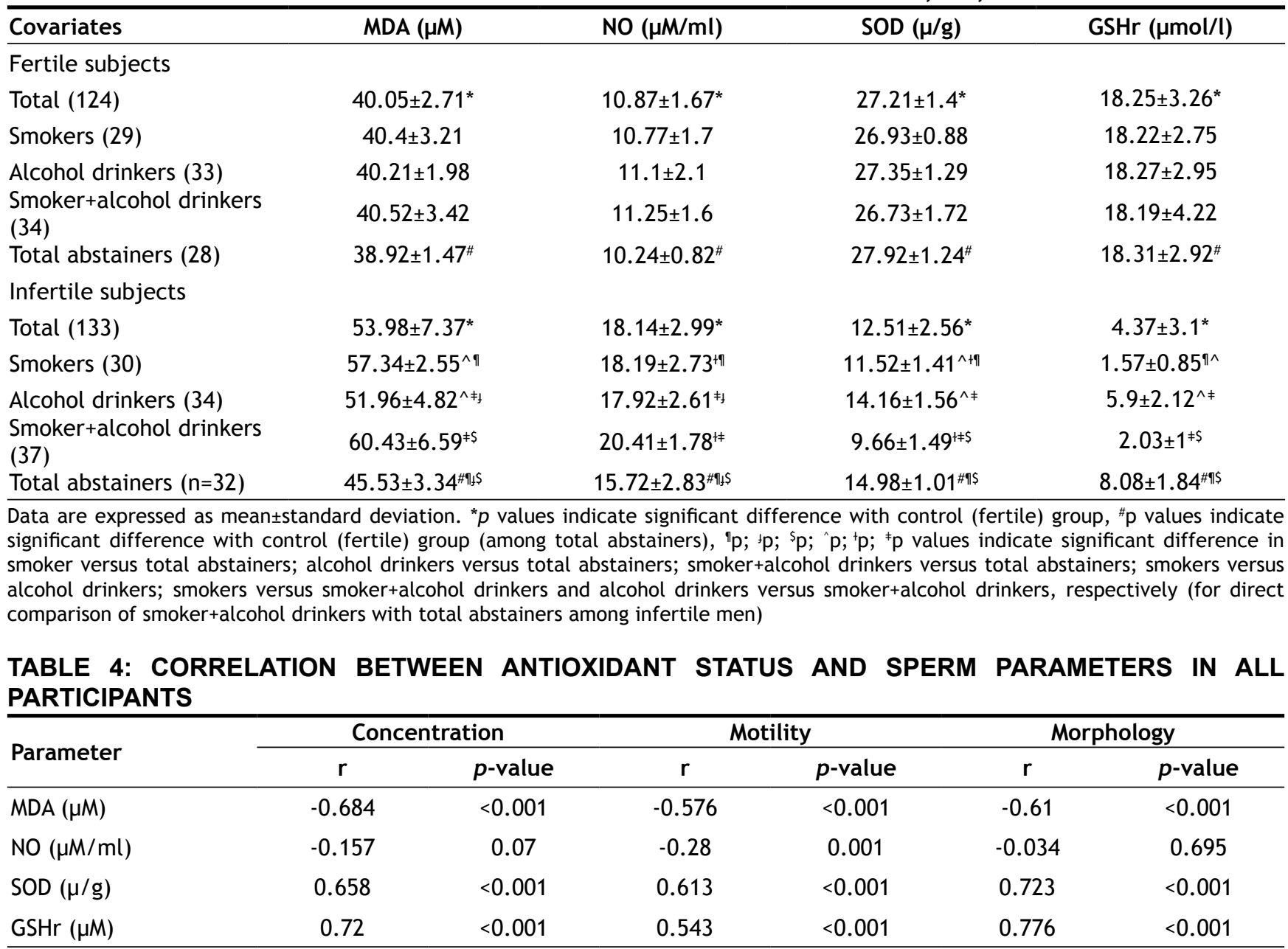

not significant; however, in infertile men values were significantly lower. Among smokers and/or alcohol drinkers groups of infertile men, smokers+alcohol drinkers group was more affected than the other exposed subgroups.

Table 4 indicates Pearson's correlation analysis between antioxidant and sperm parameters in all participants. MDA levels in serum were significantly negatively correlated with sperm concentration, motility, and morphology $(\mathrm{p}<0.001)$. NO levels in the blood plasma were also significantly negatively correlated, but only with the sperm motility ( $\mathrm{p}=0.001$ ). On the other hand, SOD and GSHr levels in blood were significantly positively associated with sperm concentration, sperm motility, and sperm morphology $(\mathrm{p}<0.001)$.

Nicotine in cigarette smoke and alcohol exert a detrimental influence on male reproductive function ${ }^{[34-36]}$. The most noteworthy findings of this study were, (i) significant lower sperm quality, elevated seminal leukocyte concentration and hormonal imbalance in smoking and/or alcohol used infertile men when compared with fertile donors according to their smoking and/or alcohol use (ii) significant elevation in MDA, NO concentrations and declining of SOD and GSHr levels in blood plasma of high dosage of smokers+alcohol drinkers group of infertile men with normal genital examination. (iii) LPO concentrations, SOD and GSHr activities were associated with sperm concentration, motility, and morphology, however, NO levels were only associated with sperm motility in smokers and/or alcohol drinkers groups of infertile men (iv) both smoking and alcohol drinking combined use affected the semen quality, male reproductive hormones and antioxidant status in infertile men more than only smoking or alcohol use.

These results agreed with the findings reported by Sharma et al. that smoking affects sperm quality, but did not agree with the results reported by Dunphy et al. alcohol consumption led to increased infertility clinic population ${ }^{[37,38]}$. However, these observations were inconsistent with the general population $^{[0,39]}$. In future, why this association differed 
between these two populations should be investigated. It is possible that because of increased ROS levels in infertile men, their antioxidant system is not as efficient as that of the general population, which could be the reason why their spermatozoa are more susceptible to cigarette smoke or alcohol. It appeared that this study is the first to report the combined effect of smoking and alcohol drinking significantly lowered semen quality in infertile men.

The detrimental effects of smoking and/or alcohol use on Sertoli and Leydig cells in the testis resulted in dysfunction of the male reproductive hormone system, which could be the cause of impaired semen quality ${ }^{[36,39]}$. Present results of abnormal hormone levels in smokers and /or alcohol drinkers groups agreed with some of the reported studies on Indian population ${ }^{[40]}$, but disagreed with other studies on different populations, which reported higher testosterone and lower LH levels $s^{[9,41,42]}$. These changes in hormone levels among diverse populations might be due to different ethnicity and race factors ${ }^{[43]}$. Otherwise, another speculation is that nicotine in cigarette smoke and alcohol caused a decrease in testosterone synthesis, which resulted in increased FSH and LH levels and lowered testosterone levels ${ }^{[4,45]}$. Results obtained showed elevated FSH, LH levels and low testosterone levels by smoking and alcohol consumption confirmed the primary testicular failure, which occurred due to the failure of the feedback regulation at the pituitary level, where damaged seminiferous tubules did not generate healthy sperms $^{[40,44,46]}$.

One of the reasons behind male infertility is excessive generation of ROS and nitrogen species, which results in oxidative stress and declining of antioxidant levels which become a real concern in recent times ${ }^{[47,48]}$. Alcohol consumption and cigarette smoking elevated ROS production, which resulted in oxidative stress and increased DNA damage subsequently ${ }^{[14,49-53]}$. Results of the present investigation showed with smoking and/or alcohol use increased oxidative stress, which is similar to that reported by Aboulmaouahib et al. but not with those regarding antioxidant activities ${ }^{[54]}$.

Increased ROS formation due to smoking and alcohol consumption might be correlated to a significant elevation in the leukocyte content in the semen of smokers and alcohol drinkers that was found in this study and confirmed by previous studies ${ }^{[1,55]}$. The particular mechanism of elevated seminal leukocyte infiltration into the semen of smokers and alcohol drinkers in infertile men is not precise and need to be elucidated further. One possible reason could be that nicotine and its water-soluble metabolite cotinine in cigarette smoke can pass through the blood-testis barrier, which allows leukocytes to enter into the seminiferous tubules to affect spermatogenesis; consequently sperm quality affected ${ }^{[56,57]}$. Another reason is that chronic alcohol use directly affects the testis, which increases seminal leukocyte infiltration, spermatozoa, and testicular autoantibodies result in testicular damage ${ }^{[58]}$. Nicotine and alcohol metabolites could induce an inflammatory condition in the male genital tract with the subsequent release of cytokines (IL-6, IL-8) ${ }^{[59,60]}$, and chemokines (CXCL5, CXCL8/IL-8) ${ }^{[61]}$. The upregulation of tolllike receptor-2/4, cyclooxygenase-2, and nuclear factor erythroid 2 (NFE2)-related factor 2 (Nrf-2) recruit and activate leukocytes in seminal plasma ${ }^{[62]}$. These activated leukocytes can produce excessive ROS in semen, resulting in oxidative stress ${ }^{[63]}$.

Further, oxidative stress elevates sperm DNA damage ${ }^{[64]}$. Male accessory gland infection (MAGI) such as prostatitis is also mediating through leukocyte production of ROS which mediated by cytokines (IL-1 $\alpha$, IL-8) and their soluble receptor (IL-1 RA) which affects sperm quality ${ }^{[65,66]}$. Therefore, decreased proinflammatory mediators could give beneficial effects on the testicular inflammatory condition. Antioxidant supplementation such as carnitine, alphatocopherol along with antiinflammatory drug therapy reduces sperm leukocyte concentration, and MAGI thus may restore the oxidative sperm balance ${ }^{[67,68]}$ (fig. 2).

Furthermore, cigarette smoke- and alcohol-induced ROS leads to peroxidation of lipids, especially docosahexaenoic acid with other polyunsaturated fatty acids in sperm membranes ${ }^{[25,69-71]}$. This excessive LPO impairs the antioxidant defence system in the male reproductive tract and leads to male infertility ${ }^{[72]}$. Results obtained in this investigation showed higher MDA concentration in the blood plasma of infertile men were similar with another Indian population study where blood and semen LPO levels were correlated positively ${ }^{[73]}$, hence smoking and alcohol exposure could be associated with elevated LPO levels. Shiva et al. described that high MDA levels were associated with low sperm concentration, motility, morphology and related to poor sperm quality, hence sperm membrane integrity ${ }^{[23]}$. Similarly, the present results indicated that MDA levels have inversely correlated with sperm 


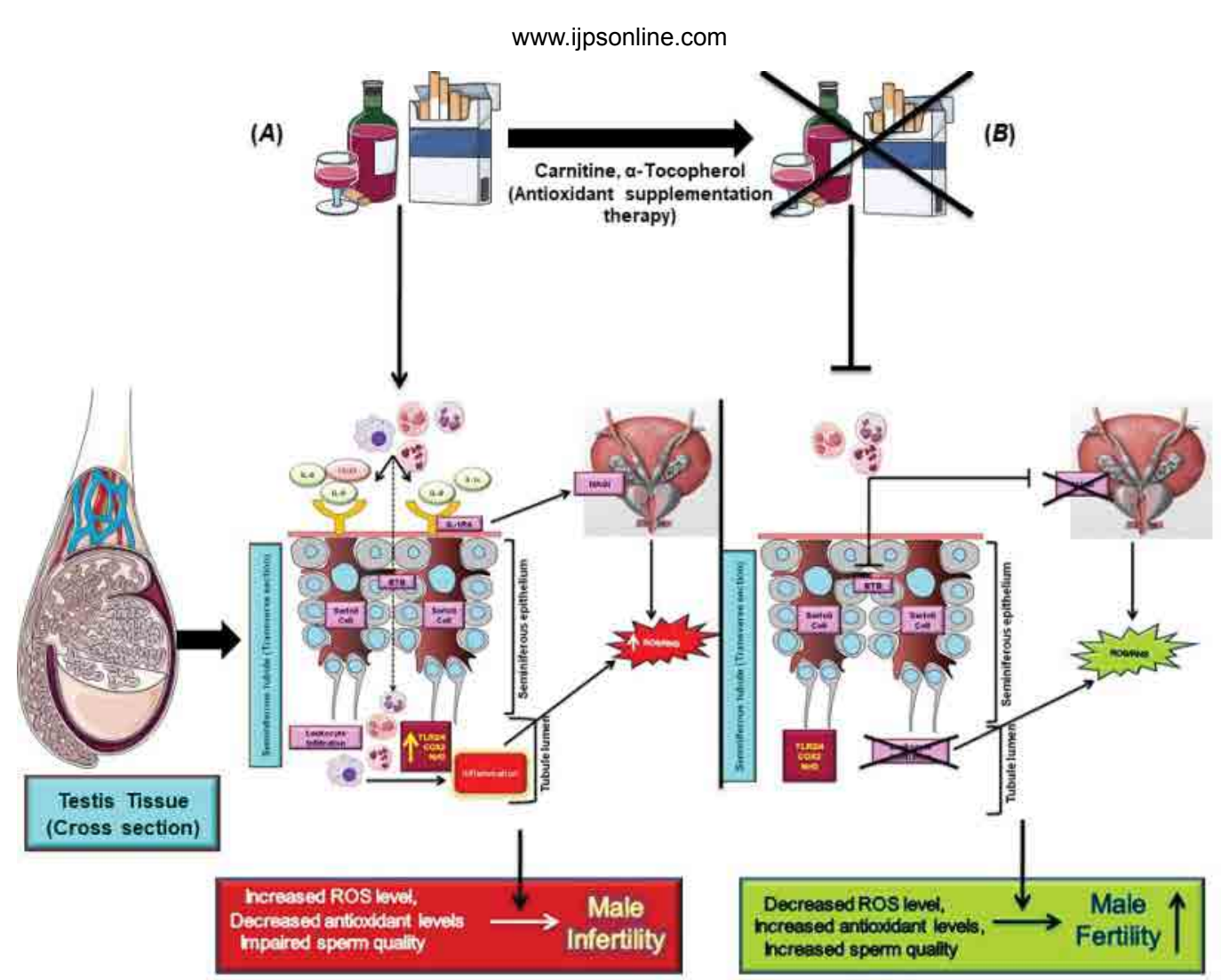

Fig. 2: Possible mechanisms of the inflammation mediated ROS in male reproductive organs

(A) smoking and alcohol use effects, cigarette and alcohol trigger infiltration of leukocytes through the blood-testis barrier mediated by cytokines, chemokines, and upregulation of TLR-2/4, COX-2, and Nrf-2 expressions. This results in inflammation of testis and male accessory gland infection (MAGI) by increasing ROS generation. (B) effects after antioxidant therapy without smoking and alcohol use- Without smoking and alcohol drinking condition, maintains redox homeostasis with normal leukocyte concentration. IL- interleukin, IL-1Ra- interleukin-1 receptor antagonist, BTB- blood-testis barrier, MAGI- male accessory gland infection, TLR2/4- toll-like receptor 2/4, COX-2- cyclooxygenase-2, Nrf2- nuclear factor erythroid 2 (NFE2)-related factor 2, ROS/RNSreactive oxygen/nitrogen species

parameters. The link between LPO and spermatozoa dysfunction might be due to the following reasons, firstly increased LPO levels could reduce membrane fluidity and loss of membrane-bound ATPase activity, which could in turn lead to loss of sperm motility. Secondly, oligozoospermic LPO could induce a refractory response to calcium signals by defective spermatozoa, which refuse to fuse with oocyte in the presence of ionophore A23187-induced acrosome reaction. Lastly, disruption of sperm membrane integrity by LPO might be responsible for abnormal sperm forms ${ }^{[74]}$. Therefore, MDA could be used as a potential oxidative stress marker for predicting ART outcomes ${ }^{[75,76]}$.

$\mathrm{NO}$ is another most prominent example of a free radical gas, which induces oxidative stress. NO increases nicotine absorption in cigarette smokers and alcohol drinkers, which affects male reproduction and fertilization ${ }^{[18,77]}$. Taken et al. noted that higher levels of NO concentrations in blood were negatively correlated with the sperm motility, which is similar to our observations ${ }^{[26]}$. Reasons behind the correlation of NO and sperm motility are such as, a moderate amount of NO is necessary for acrosome reaction and sperm capacitation $^{[77]}$. Furthermore, another reason is that when NO stimulates sperm motility via the activation of soluble guanylate cyclase, which increases cyclic guanosine monophosphate (cGMP) levels leading to activation of protein kinase G. But, when the cGMP physiological levels were impaired by NO-induced stress, human sperm motility also gets affected ${ }^{[78]}$. Studies reported that sperm motility was decreased by sodium nitroprusside, which releases $\mathrm{NO}^{[79]}$. eNOS, iNOS are essential in the normal physiology of spermatozoa, but their aberrant expressions are associated with abnormal sperm motility ${ }^{[80]}$ and disturbance of steady concentration in the testis, respectively ${ }^{[81]}$.

The balance between ROS generation and antioxidant defence system is disturbed, when the cellular scavenging systems cannot eliminate the increased level of ROS, which results in spermatozoa damage ${ }^{[82]}$. 
The scavenging potential in gonads and seminal fluid is usually maintained by sufficient levels of SOD and GSHr. SOD has been found in Sertoli cells, germ cells $^{[83]}$, epididymis and male accessory sex glands, whereas GSH found in testes ${ }^{[20,84]}$.

In the present study lower levels of SOD and GSHr could be correlated with lower sperm quality, which is similar to earlier studies in infertility clinical population ${ }^{[23,85,86]}$. In testis, first SOD is involved in scavenging oxygen radicals, and its availability is also more than other isoenzymes ${ }^{[85,87,88]}$. If SOD activity is reduced, then SOD levels would also be reduced in germ cells and 8-OHdG levels get increased; hence, cell apoptosis would occur. Therefore, decreased activity of SOD is correlated to increased susceptibility of spermatogenic cells to ROS; thus oxidative stress might be the reason for the correlation of SOD and reduced sperm quality in our study.

Reduced activity of SOD in the presence cigarette smoking and xanthine oxidase is due to the accumulation of superoxide $\left(\mathrm{O}_{2}^{-\bullet}\right)$, hydrogen peroxide $\left(\mathrm{H}_{2} \mathrm{O}_{2}\right)$, or the products of its decomposition ${ }^{[77]}$. $\mathrm{O}_{2}^{-\bullet}$, $\mathrm{H}_{2} \mathrm{O}_{2}$ are generated by NAPDH oxidase by reducing the activity of SOD, whereas reduced GSHr levels is responsible for hydroperoxides $(\mathrm{OH}-\bullet)$ production, including $\mathrm{H}_{2} \mathrm{O}_{2}$, which is driven by Fenton reaction ${ }^{[89]}$.

Decreased level of GSHr during spermatogenesis indicated loss of integrity of spermatozoa integrity, which resulted in oxidative stress ${ }^{[00]}$. GSH is not only essential for sperm scavenging system but also vital for the production of phospholipid hydroperoxide glutathione peroxidase (GPX4), which exists in spermatids and is essential for the formation of a protein required for development of the midpiece of spermatozoa. Absence of either substance could lead to deformation of the midpiece and malfunctioned motility ${ }^{[91]}$. Furthermore, GPx and GSH reductase might be responsible for the inhibition of sperm peroxidation $^{[92]}$. Moreover, smoking and alcohol drinking also suppress Nrf2 expression, which has a protective role against oxidative damage ${ }^{[93]}$ (fig. 3).

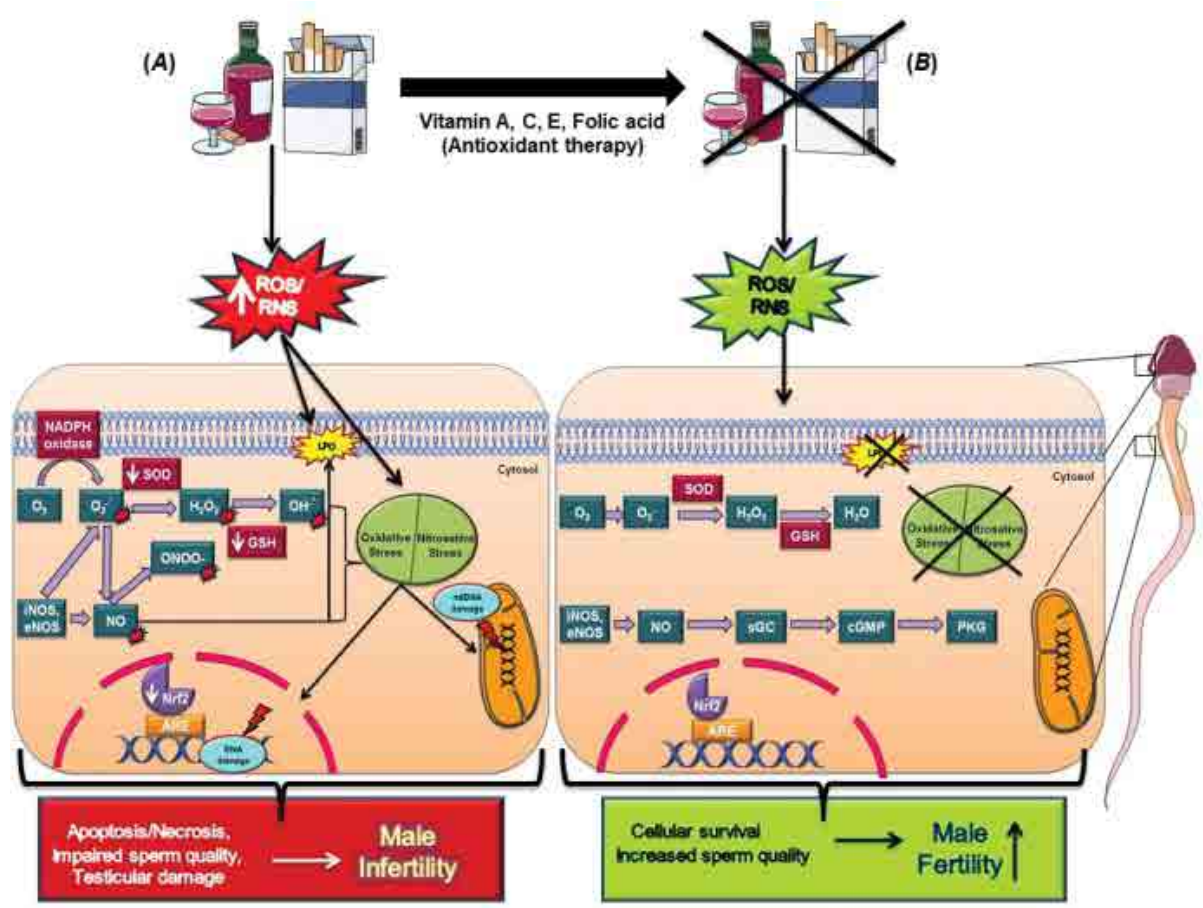

Fig. 3: Likely intracellular oxidative mechanisms in spermatozoa

(A) smoking and alcohol use effects; cigarette and alcohol increase ROS level possibly induced by increased NADPH oxidase activity, which suppresses SOD, GSH and Nrf2 levels by producing reactive oxygen intermediates $\left(\mathrm{O}_{2}^{-\bullet}, \mathrm{H}_{2} \mathrm{O}_{2}\right.$ and $\left.\mathrm{OH}^{-\bullet}\right)$. When uncoupled eNOS reacts with $\mathrm{NO}$ and $\mathrm{O}_{2}^{-\bullet}$ to forms ONOO-. Increased ROS/RNS level results in oxidative/nitrosative stress, which induces sperm membrane peroxidation and leads to nuclear as well as mitochondrial DNA damage. (B) effects after antioxidant therapy without smoking and alcohol use- in the absence of cigarette or alcohol exposure, ROS production is eliminated by spermatozoa in the form of $\mathrm{H} 2 \mathrm{O}$ and $\mathrm{NO}$, stimulates sperm capacitation and acrosome reaction via cGMP/PKG pathway. These signalling pathways do not allow sperm DNA damage. ROS/RNS- reactive oxygen/nitrogen species, NADPH- nicotinamide adenine

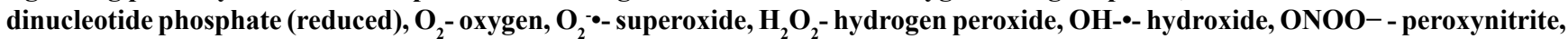
NO- nitric oxide, iNOS- inducible NO synthase, eNOS- endothelial NOS, SOD- superoxide dismutase, GSH- glutathione, LPO- lipid peroxidation, Nrf2- nuclear factor erythroid 2 (NFE2)-related factor 2, ARE- antioxidant response element, mtDNA- mitochondrial deoxyribonucleic acid, sGC- soluble guanylyl cyclase, cGMP- cyclic guanosine monophosphate, PKG- protein kinase G 
Marselos et al. have noted that the nicotine compound in a cigarette can influence the enzymes of ethanol metabolism in the body. It may be possible that the combination of ethanol and nicotine induces excessive production of ROS than that of ethanol or nicotine alone ${ }^{[94]}$. This study supports our findings regarding the combined use of smoking and alcohol drinking affected antioxidant status more in infertile men than smoking or alcohol use alone.

As per our knowledge, the correlations that have shown between blood plasma levels of MDA, NO, SOD and GSHr and cigarette smoking, alcohol consumption have not been previously conducted. These novel findings discovered that toxic compounds in cigarette and alcohol imbalance the ROS and antioxidant system and affects sperm DNA integrity, which increases DNA fragmentation, hence lead to cell apoptosis. These unfavourable effects of oxidative stress can be treated with oral antioxidants such as vitamins $\mathrm{C}$ and E, zinc, folic acid, SOD and GSHr to enhance the fertility potential in men through redox homeostasis ${ }^{[95]}$. However, these antioxidant supplementations might not be adequate to regulate oxidative stress and maintain a healthy reproductive tract. Furthermore, paternal preconception alcohol use is associated with an increased risk of spontaneous loss of pregnancy ${ }^{[96]}$.

On the other hand, paternal smoking is associated with a high risk of congenital diseases and childhood cancers in their children ${ }^{[97]}$. Wherever both paternal and maternal smoking is independently associated with decreased sperm quality of their offspring ${ }^{[98]}$. These overall findings suggest that when a couple wishes to conceive, it would be safe to quit smoking and alcohol consumption $^{[5,99]}$.

There are some limitations in this study, which needs to be mentioned before drawing conclusions of this investigation. In the present study, smoking and alcohol drinking statistics were obtained from a prepared questionnaire which asks the subjects to mention the number of cigarettes smoked per day, alcohol consumed per day including the duration in years. This data was not confirmed by any biochemical test such as ethanol or cotinine levels in serum, salivary, or urine samples. Hence, the nature of data is qualitative; hence a definite correlation between smoking or alcohol drinking habits with semen parameters could not be made.

Furthermore, as per the excluding criteria, which included avoiding of recreational drug use, abnormalities of genital examination lead to decreased number of participants in the study and also in the subgroups of patients and controls. Therefore, dosedependent variables such as the number of cigarettes or drinks consumed per day and the duration of smoking and alcohol drinking habits could not be focused on. In future, a prospective, large sample-sized study should be conducted with active smokers and alcohol drinkers to examine the effects of smoking and alcohol drinking in infertile men at different time intervals and also after they stop smoking or alcohol drinking, which would give a better idea on the relationship between cigarette smoking and male infertility. In spite of these limitations, significant links were found in the present study such as a correlation between cigarette smoking and alcohol drinking with increased concentrations of oxidative stress markers, which might be due to increased seminal leukocyte concentrations.

In the present study, it can be concluded that smoking and alcohol consumption leads to decreased sperm quality, impaired male endocrine system and oxidative damage in the blood plasma of infertile men. These findings suggested that cigarette smoke and alcohol have a deleterious effect on the male reproductive system. Further investigation of the role of toxic compounds in cigarette smoke and alcohol metabolism with specific biochemical and molecular mechanism related to sperm dysfunction is necessary. This investigation definitely resolved some controversies regarding the effect of smoking and alcohol consumption on fertility potential of infertile men.

\section{Acknowledgments:}

The authors thank their patients and Dr. Sandhya Babu, Sandhya Hospital, Vellore, India, for providing the required samples. The authors are garteful to the management of VIT for providing the required facilities to carry out this study. The VIT seed grant supported this work. The author Shalaka S Ramgir gratefully acknowledges financial assistance from VIT.

\section{Conflict of interest}

The authors reported no conflict of interest.

\section{REFERENCES}

1. Varghese AC, du Plessis SS, Agarwal A. Male gamete survival at stake: causes and solutions. Reprod Biomed Online 2008;17(6):866-80.

2. Matzuk MM, Lamb DJ. Genetic dissection of mammalian fertility pathways. Nat Med 2002;8(10):S33.

3. Barazani Y, Katz BF, Nagler HM, Stember DS. Lifestyle, 
environment, and male reproductive health. Urol Clin North Am 2014;41(1):55-66.

4. Benoff S, Jacob A, Hurley IR. Male infertility and environmental exposure to lead and cadmium. Hum Reprod Update 2000;6(2):107-21.

5. Sharma R, Biedenharn KR, Fedor JM, Agarwal A. Lifestyle factors and reproductive health: taking control of your fertility. Reprod Biol Endocrinol 2013;11(1):66.

6. Sharpe RM. Lifestyle and environmental contribution to male infertility. Br Med Bull 2000;56(3): 630-42.

7. Wogatzky J, Wirleitner B, Stecher A, Vanderzwalmen P, Neyer A, Spitzer D, et al. The combination matters-distinct impact of lifestyle factors on sperm quality: a study on semen analysis of 1683 patients according to MSOME criteria. Reprod Biol Endocrinol 2012;10(1):115.

8. Li Y, Lin H, Li Y, Cao J. Association between socio-psychobehavioral factors and male semen quality: systematic review and meta-analyses. Fertil Steril 2011;95(1):116-23.

9. Jensen TK, Swan S, Jørgensen N, Toppari J, Redmon B, Punab M, et al. Alcohol and male reproductive health: a crosssectional study of 8344 healthy men from Europe and the USA. Hum Reprod 2014;29(8):1801-9.

10. Yang H, Chen Q, Zhou N, Sun L, Bao H, Tan L, et al. Lifestyles associated with human semen quality: results from MARHCS cohort study in Chongqing, China. Medicine 2015;94(28):e1166.

11. Saleh RA, Agarwal A, Sharma RK, Nelson DR, Thomas Jr AJ. Effect of cigarette smoking on levels of seminal oxidative stress in infertile men: a prospective study. Fertil Steril 2002;78(3):491-9.

12. Mostafa T, Tawadrous G, Roaia MM, Amer MK, Kader RA, Aziz A. Effect of smoking on seminal plasma ascorbic acid in infertile and fertile males. Andrologia 2006;38(6):221-4.

13. Mostafa T. Cigarette smoking and male infertility. J Adv Res 2010;1(3):179-86.

14. Sepaniak S, Forges T, Gerard H, Foliguet B, Bene MC, Monnier-Barbarino P. The influence of cigarette smoking on human sperm quality and DNA fragmentation. Toxicology 2006;223(1-2):54-60.

15. Taha EA, Ez-Aldin AM, Sayed SK, Ghandour NM, Mostafa T. Effect of smoking on sperm vitality, DNA integrity, seminal oxidative stress, zinc in fertile men. Urology 2012;80(4):822-5.

16. Das SK, Vasudevan DM. Alcohol-induced oxidative stress. Life Sci 2007;81(3):177-87.

17. Wu D, Cederbaum AI. Alcohol, oxidative stress, and free radical damage. Alcohol Res Health 2003;27(4):277-85.

18. Maneesh M, Jayalekshmi H. Role of reactive oxygen species and antioxidants on pathophysiology of male reproduction. Indian J Clin Biochem 2006;21(2):80-9.

19. Varshini J, Srinag BS, Kalthur G, Krishnamurthy H, Kumar $\mathrm{P}$, Rao SS, et al. Poor sperm quality and advancing age are associated with increased sperm DNA damage in infertile men. Andrologia 2012;44:642-9.

20. Ben Abdallah F, Dammak I, Attia H, Hentati B, Ammar-Keskes L. Lipid peroxidation and antioxidant enzyme activities in infertile men: correlation with semen parameter. J Clin Lab Anal 2009;23(2):99-104.

21. Atig F, Kerkeni A, Saad A, Ajina M. Effects of reduced seminal enzymatic antioxidants on sperm DNA fragmentation and semen quality of Tunisian infertile men. J Assist Reprod Genet 2017;34(3):373-81.

22. Khosrowbeygi A, Zarghami N. Levels of oxidative stress biomarkers in seminal plasma and their relationship with seminal parameters. BMC Cell Biol 2007;7(1):6.

23. Shiva M, Gautam AK, Verma Y, Shivgotra V, Doshi H, Kumar S. Association between sperm quality, oxidative stress, and seminal antioxidant activity. Clin Biochem 2011;44(4):31924.

24. Benedetti S, Tagliamonte MC, Catalani S, Primiterra M, Canestrari F, De Stefani S, et al. Differences in blood and semen oxidative status in fertile and infertile men, and their relationship with sperm quality. Reprod Biol Endocrinol 2012;25(3):300-6.

25. Oborna I, Wojewodka G, De Sanctis JB, Fingerova H, Svobodova M, Brezinova J, et al. Increased lipid peroxidation and abnormal fatty acid profiles in seminal and blood plasma of normozoospermic males from infertile couples. Hum Reprod 2009;25(2):308-16.

26. Taken K, Alp HH, Eryilmaz R, Donmez MI, Demir M, Gunes $\mathrm{M}$, et al. Oxidative DNA damage to sperm cells and peripheral blood leukocytes in infertile men. Med Sci Monit 2016;22:4289.

27. World Health Organization. WHO Laboratory Manual for the Examination and Processing of Human Semen. 5th ed. Switzerland: WHO Press; 2010.

28. Eroglu M, Sahin S, Durukan B, Ozakpinar OB, Erdinc N, Turkgeldi L, et al. Blood serum and seminal plasma selenium, total antioxidant capacity and coenzyme q10 levels in relation to semen parameters in men with idiopathic infertility. Biol Trace Elem Res 2014;159(1-3):46-51.

29. Jiang LL, Xie JK, Cui JQ, Wei D, Yin BL, Zhang YN, et al. Promoter methylation of yes-associated protein (YAP1) gene in polycystic ovary syndrome. Medicine 2017;96(2):e5768.

30. Gartaganis SP, Patsoukis NE, Nikolopoulos DK, Georgiou CD. Evidence for oxidative stress in lens epithelial cells in pseudoexfoliation syndrome. Eye (Lond) 2007;21(11):1406.

31. Miranda KM, Espey MG, Wink DA. A rapid, simple spectrophotometric method for simultaneous detection of nitrate and nitrite. Nitric Oxide 2001;5(1):62-71.

32. Ewing JF, Janero DR. Microplate superoxide dismutase assay employing a nonenzymatic superoxide generator. Anal Biochem 1995;232(2):243-8.

33. Bradford MM. A rapid and sensitive method for the quantitation of microgram quantities of protein utilizing the principle of protein-dye binding. Anal Biochem 1976;72(12):248-54.

34. Ezzatabadipour M, Azizollahi S, Sarvazad A, Mirkahnooj Z, Mahdinia Z, Nematollahi-Mahani SN. Effects of concurrent chronic administration of alcohol and nicotine on rat sperm parameters. Andrologia 2012;44(5):330-6.

35. Arabi M. Nicotinic infertility: assessing DNA and plasma membrane integrity of human spermatozoa. Andrologia 2004;36(5):305-10.

36. La Vignera S, Condorelli RA, Balercia G, Vicari E, Calogero AE. Does alcohol have any effect on male reproductive function? A review of literature. Asian J Androl 2013;15(2):221.

37. Sharma R, Harlev A, Agarwal A, Esteves SC. Cigarette smoking and semen quality: a new meta-analysis examining the effect of the 2010 World Health Organization laboratory methods for the examination of human semen. Eur Urol 2016;70(4):635-45.

38. Dunphy BC, Barratt CL, Cooke ID. Male alcohol consumption 
and fecundity in couples attending an infertility clinic. Andrologia 1991;23(3):219-21.

39. Vine MF. Smoking and male reproduction: a review. Int $\mathbf{J}$ Androl 1996;19(6):323-37.

40. Mitra A, Chakraborty B, Mukhopadhay D, Pal M, Mukherjee $\mathrm{S}$, Banerjee $\mathrm{S}$, et al. Effect of smoking on semen quality, FSH, testosterone level, and CAG repeat length in androgen receptor gene of infertile men in an Indian city. Syst Biol Reprod Med 2012;58(5):255-62.

41. Lotti F, Corona G, Vitale P, Maseroli E, Rossi M, Fino MG, et al. Current smoking is associated with lower seminal vesicles and ejaculate volume, despite higher testosterone levels, in male subjects of infertile couples. Hum Reprod 2015;30(3):590-602.

42. Trummer H, Habermann H, Haas J, Pummer K. The impact of cigarette smoking on human semen parameters and hormones. Hum Reprod 2002;17(6):1554-9.

43. Punjani N, Nayan M, Grober E, Lo K, Lau S, Jarvi K. MP1911 The effect of ethnicity and race on semen analysis and hormones in the infertile patient. J Urol 2018;199(4):e248.

44. Muthusami KR, Chinnaswamy P. Effect of chronic alcoholism on male fertility hormones and semen quality. Fertil Steril 2005;84(4):919-24.

45. Maneesh M, Dutta S, Chakrabarti A, Vasudevan DM. Alcohol abuse-duration dependent decrease in plasma testosterone and antioxidants in males. Indian $\mathrm{J}$ Physiol Pharmacol 2006;50(3):291.

46. Bhasin S. Approach to the infertile man. J Clin Endocrinol Metab 2007;92(6):1995-2004.

47. Agarwal A, Allamaneni SS. Role of free radicals in female reproductive diseases and assisted reproduction. Reprod Biomed Online 2004;9(3):338-47.

48. Doshi SB, Khullar K, Sharma RK, Agarwal A. Role of reactive nitrogen species in male infertility. Reprod Biol Endocrinol 2012;10(1):109.

49. Calogero A, Polosa R, Perdichizzi A, Guarino F, La Vignera S, Scarfia A, et al. Cigarette smoke extract immobilizes human spermatozoa and induces sperm apoptosis. Reprod Biomed Online 2009;19(4):564-71.

50. Cederbaum AI, $\mathrm{Lu} \mathrm{Y,} \mathrm{Wu} \mathrm{D.} \mathrm{Role} \mathrm{of} \mathrm{oxidative} \mathrm{stress} \mathrm{in}$ alcohol-induced liver injury. Arch Toxicol 2009;83(6):519-48.

51. Koch OR, Pani G, Borrello S, Colavitti R, Cravero A, Farrè $\mathrm{S}$, et al. Oxidative stress and antioxidant defenses in ethanolinduced cell injury. Mol Aspects Med 2004;25(1-2):191-8.

52. Saleh RA, Agarwal A, Nada EA, El-Tonsy MH, Sharma RK, Meyer A, et al. Negative effects of increased sperm DNA damage in relation to seminal oxidative stress in men with idiopathic and male factor infertility. Fertil Steril 2003;79:1597-605.

53. Viloria T, Garrido N, Fernández JL, Remohí J, Pellicer A, Meseguer M. Sperm selection by swim-up in terms of deoxyribonucleic acid fragmentation as measured by the sperm chromatin dispersion test is altered in heavy smokers. Fertil Steril 2007;88(2):523-5.

54. Aboulmaouahib S, Madkour A, Kaarouch I, Sefrioui O, Saadani B, Copin H, et al. Impact of alcohol and cigarette smoking consumption in male fertility potential: Looks at lipid peroxidation, enzymatic antioxidant activities and sperm DNA damage. Andrologia 2018;50(3):e12926.

55. Close CE, Roberts PL, Berger RE. Cigarettes, alcohol and marijuana are related to pyospermia in infertile men. J Urol 1990;144(4):900-3.
56. Sepaniak S, Forges T, Monnier-Barbarino P. Consequences of cigarette smoking on male fertility. J Gynecol Obstet Biol Reprod 2005;34:3S102-11.

57. Vine MF, Hulka BS, Margolin BH, Truong YK, Hu PC, Schramm MM, et al. Cotinine concentrations in semen, urine, and blood of smokers and nonsmokers. Am J Public Health 1993;83(9):1335-8.

58. Van Thiel DH, Gavaler JS, Smith WI, Rabin BS. Testicular and spermatozoal autoantibody in chronic alcoholic males with gonadal failure. Clin Immunol Immunopathol 1977;8(2):3117.

59. Eggert-Kruse W, Boit R, Rohr G, Aufenanger J, Hund M, Strowitzki T. Relationship of seminal plasma interleukin (IL)8 and IL-6 with semen quality. Hum Reprod 2001;16(3):51728.

60. Pannekoek Y, Trum JW, Bleker OP, Van Der Veen F, Spanjaard L, Dankert J. Cytokine concentrations in seminal plasma from subfertile men are not indicative of the presence of Ureaplasma urealyticum or Mycoplasma hominis in the lower genital tract. J Med Microbiol 2000;49(8):697-700.

61. McDowell KL, Begley LA, Mor-Vaknin N, Markovitz DM, Macoska JA. Leukocytic promotion of prostate cellular proliferation. Prostate 2010;70(4):377-89.

62. Hagan S, Khurana N, Chandra S, Abdel-Mageed AB, Mondal D, Hellstrom WJ, et al. Differential expression of novel biomarkers (TLR-2, TLR-4, COX-2, and Nrf-2) of inflammation and oxidative stress in semen of leukocytospermia patients. Andrology 2015;3(5):848-55.

63. Aitken RJ, Buckingham DW, Brindle J, Gomez E, Baker HG, Irvine DS. Andrology: Analysis of sperm movement in relation to the oxidative stress created by leukocytes in washed sperm preparations and seminal plasma. Hum Reprod 1995;10(8):2061-71.

64. Sabeti P, Pourmasumi S, Rahiminia T, Akyash F, Talebi AR. Etiologies of sperm oxidative stress. Int J Reprod Biomed 2016;14(4):231.

65. Depuydt CE, Bosmans E, Zalata A, Schoonjans F, Comhaire $\mathrm{FH}$. The relation between reactive oxygen species and cytokines in andrological patients with or without male accessory gland infection. J Androl 1996;17(6):699-707.

66. Dziadecki W, Celinska A, Fracki S, Bablok L, Barcz E. Interleukin 6 and interleukin 8 concentrations in seminal plasma of male with seminogram abnormalities. Cent Eur J Immunol 2010;35(3):162-7.

67. Therond P, Auger J, Legrand A, Jouannet P. $\alpha$-Tocopherol in human spermatozoa and seminal plasma: relationships with motility, antioxidant enzymes and leukocytes. Mol Hum Reprod 1996;2(10):739-44.

68. Vicari E, La Vignera S, Calogero AE. Antioxidant treatment with carnitines is effective in infertile patients with prostatovesiculoepididymitis and elevated seminal leukocyte concentrations after treatment with nonsteroidal antiinflammatory compounds. Fertil Steril 2002;78(6):1203-8.

69. Church DF, Pryor WA. Free-radical chemistry of cigarette smoke and its toxicological implications. Environ Health Perspect 1985;64:111-26.

70. Sultatos LG. Effects of acute ethanol administration on the hepatic xanthine dehydrogenase/oxidase system in the rat. J Pharmacol Exp Ther 1988;246(3):946-9.

71. Wu D, Zhai Q, Shi X. Alcohol-induced oxidative stress and cell responses. J Gastroenterol Hepatol 2006;21:S26-9.

72. Sanocka D, Miesel R, Jędrzejczak P, Chełmonska-Soyta A, 
Kurpisz M. Effect of reactive oxygen species and the activity of antioxidant systems on human semen; association with male infertility. Int J Androl 1997;20(5):255-64.

73. Mahanta R, Gogoi A, Chaudhury PN, Roy S, Bhattacharyya IK, Sharma P. Association of oxidative stress biomarkers and antioxidant enzymatic activity in male infertility of north-East India. J Obstet Gynaecol India 2012;62(5):546-50.

74. Sharma RK, Agarwal A. Role of reactive oxygen species in male infertility. Urology 1996;48(6):835-50.

75. Jedrzejczak P, Fraczek M, Szumała-Kakol A, TaszarekHauke G, Pawelczyk L, Kurpisz M. Consequences of semen inflammation and lipid peroxidation on fertilization capacity of spermatozoa in in vitro conditions. Int J Androl 2005;28(5):275-83.

76. Oral O, Kutlu T, Aksoy E, Fıçıcıoğlu C, Uslu H, Tuğrul S. The effects of oxidative stress on outcomes of assisted reproductive techniques. J Assist Reprod Genet 2006;23(2):81-5.

77. Balercia G, Moretti S, Vignini A, Magagnini M, Mantero $\mathrm{F}$, Boscaro $\mathrm{M}$, et al. Role of nitric oxide concentrations on human sperm motility. J Androl 2004;25(2):245-9.

78. Chan YM, Chan SY, Tucker MJ, Wong CJ, Leung CK, Leong MK. Effects of dibutyryl cyclic guanosine monophosphate on human spermatozoal motility and penetration of zona-free hamster oocytes. Hum Reprod 1990;5(3):304-8.

79. Weinberg JB, Doty E, Bonaventura J, Haney AF. Nitric oxide inhibition of human sperm motility. Fertil Steril 1995;64(2):408-13.

80. O’Bryan MK, Zini A, Cheng CY, Schlegel PN. Human sperm endothelial nitric oxide synthase expression: correlation with sperm motility. Fertil Steril 1998;70:1143-7.

81. Lee NPY, Cheng CY. Nitric oxide/nitric oxide synthase, spermatogenesis, and tight junction dynamics. Biol Reprod 2004;70:267-76.

82. Aitken RJ, Koppers AJ. Apoptosis and DNA damage in human spermatozoa. Asian J Androl 2011;13(1):36.

83. Bauché F, Fouchard MH, Jégou B. Antioxidant system in rat testicular cells. FEBS Lett 1994;349(3):392-6.

84. Chen H, Chow PH, Cheng SK, Cheung AL, Cheng LY, O WS. Male genital tract antioxidant enzymes: their source, function in the female, and ability to preserve sperm DNA integrity in the golden hamster. J Androl 2003;24(5):704-11.

85. Atig F, Raffa M, Habib BA, Kerkeni A, Saad A, Ajina M. Impact of seminal trace element and glutathione levels on semen quality of Tunisian infertile men. BMC Urol 2012;12(1):6.

86. Husain K, Scott BR, Reddy SK, Somani SM. Chronic ethanol and nicotine interaction on rat tissue antioxidant defense system. Alcohol 2001;25(2):89-97.
87. Marklund SL. Superoxide dismutase in human tissues, cells and extracellular fluids: clinical implications. In: Johnson JE, Walford R, Harman D, Miguel J, editors. Free Radicals, Aging, and Degenerative Diseases. New York: Alan R. Liss; 1986. p. 509-26.

88. Celino FT, Yamaguchi S, Miura C, Ohta T, Tozawa Y, Iwai T, et al. Tolerance of spermatogonia to oxidative stress is due to high levels of $\mathrm{Zn}$ and $\mathrm{Cu} / \mathrm{Zn}$ superoxide dismutase. PlosOne 2011;6(2):e16938.

89. Griveau JF, Dumont E, Renard P, Callegari JP, Le Lannou D. Reactive oxygen species, lipid peroxidation and enzymatic defence systems in human spermatozoa. J Reprod Fertil 1995;103(1):17-26.

90. Bhardwaj A, Verma A, Majumdar S, Khanduja KL. Status of vitamin $\mathrm{E}$ and reduced glutathione in semen of oligozoospermic and azoospermic patients. Asian J Androl 2000;2(3):225-8.

91. Ursini F, Heim S, Kiess M, Maiorino M, Roveri A, Wissing J, et al. Dual function of the selenoprotein PHGPx during sperm maturation. Science 1999;285(5432):1393-6.

92. Lenzi A, Picardo M, Gandini L, Lombardo F, Terminali O, Passi S, et al. Andrology: Glutathione treatment of dyspermia: effect on the lipoperoxidation process. Hum Reprod 1994;9(11):2044-50.

93. Elsamanoudy A, Shaalan D, Abo El-khair SM, Helaly A. NRF2 gene expression and DNA fragmentation markers as possible predictors of chronic smoking induced spermatozoa dysfunction in infertility with normal seminogram. Human Andrology 2017;7(4):127-35.

94. Marselos M, Vasiliou V, Malamasi M, Alikaridis F, Kefalas T. Effects of Cannabis and Tobacco on the Ezymes of Alcohol Metabolism in the Rat. Rev Environ Health 1991;9(1):31-8.

95. Gharagozloo P, Aitken RJ. The role of sperm oxidative stress in male infertility and the significance of oral antioxidant therapy. Hum Reprod 2011;26(7):1628-40.

96. Henriksen TB, Hjollund NH, Jensen TK, Bonde JP, Andersson $\mathrm{AM}$, Kolstad $\mathrm{H}$, et al. Alcohol consumption at the time of conception and spontaneous abortion. Am J Epidemiol 2004;160(7):661-7.

97. Esakky P, Moley KH. Paternal smoking and germ cell death: a mechanistic link to the effects of cigarette smoke on spermatogenesis and possible long-term sequelae in offspring. Mol Cell Endocrinol 2016;435:85-93.

98. Axelsson J, Rylander L, Rignell-Hydbom A, Silfver KA, Stenqvist A, Giwercman A. The impact of paternal and maternal smoking on semen quality of adolescent men. PloS One 2013;8(6):e66766.

99. Ménézo Y, Entezami F, Lichtblau I, Cohen M, Belloc S, Brack M. Oxidative stress and fertility: false evidence and bad recipes. Gynecol Obstet Ferti 2012;40(12):787-96. 